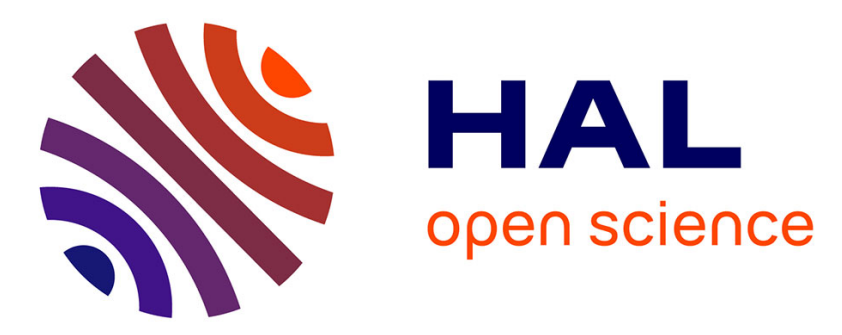

\title{
Metals in microplastics: determining which are additive, adsorbed, and bioavailable
}

Charlotte Catrouillet, Mélanie Davranche, Imane Khatib, Corentin Fauny, Aurélie Wahl, Julien Gigault

\section{- To cite this version:}

Charlotte Catrouillet, Mélanie Davranche, Imane Khatib, Corentin Fauny, Aurélie Wahl, et al.. Metals in microplastics: determining which are additive, adsorbed, and bioavailable. Environmental Science: Processes \& Impacts, 2021, 23 (4), pp.553-558. 10.1039/D1EM00017A . insu-03172182

\section{HAL Id: insu-03172182 \\ https://hal-insu.archives-ouvertes.fr/insu-03172182}

Submitted on 19 Apr 2021

HAL is a multi-disciplinary open access archive for the deposit and dissemination of scientific research documents, whether they are published or not. The documents may come from teaching and research institutions in France or abroad, or from public or private research centers.
L'archive ouverte pluridisciplinaire HAL, est destinée au dépôt et à la diffusion de documents scientifiques de niveau recherche, publiés ou non, émanant des établissements d'enseignement et de recherche français ou étrangers, des laboratoires publics ou privés. 
8

9

10 $\underline{\text { rennes1.fr }}$

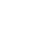

\section{Letter: Metals in microplastics: determining which}

\section{are additive, adsorbed, and bioavailable}

Charlotte Catrouillet ${ }^{\mathrm{a}^{*}}$, Mélanie Davranche ${ }^{\mathrm{a}}$, Imane Khatib ${ }^{\mathrm{a}}$, Corentin Fauny ${ }^{\mathrm{a}}$, Aurélie Wahl ${ }^{\mathrm{a}}$, Julien Gigault ${ }^{\mathrm{a}, \mathrm{b}^{*}}$

aUniv. Rennes, CNRS, Géosciences Rennes - UMR 6118, F-35000 Rennes, France

${ }^{\text {b} T A K U V I K ~ C N R S / U L a v a l, ~ U M I 3376, ~ U n i v e r s i t e ́ ~ L a v a l, ~ Q u e b e c ~ C i t y, ~ Q C, ~ C a n a d a ~}$

*Corresponding authors: julien.gigault@takuvik.ulaval.ca and charlotte.catrouillet@univ-

11

12 
13 Abstract: Microplastics from the North Atlantic Gyre deposited on Guadeloupe beaches 14 were sampled and characterized. A new method was developed to identify which elements 15 were present as additives in these microplastics. The method used both acidic leaching and 16 acidic digestion. Using this original method, several elements ( $\mathrm{Al}, \mathrm{Zn}, \mathrm{Ba}, \mathrm{Cu}, \mathrm{Pb}, \mathrm{Cd}, \mathrm{Mn}$, $17 \mathrm{Cr}$ ) were identified as pigments. Furthermore, some elements used as additives to plastics 18 (especially the non-essential elements) seem to contribute to most of the acidic leaching, 19 suggesting that these additives can leach and readsorb onto the surface of microplastics, 20 becoming bioavailable. Based on the element content in the acidic leaching, only Cd should 21 represent a danger for fish when ingested. However, further studies are needed to determine 22 the potential synergetic effect on health caused by the ingestion of several elements and 23 microplastics. 


\section{Introduction}

28 Thousands of metric tons of plastics debris ${ }^{1}$ have been released into the environment since the 1950s, and the public is becoming ever-more aware of the negative impacts of plastic debris on living organisms. These impacts can occur directly through the presence or accumulation of plastics, or indirectly via their associated pollutants (organic and inorganic), also known as the Trojan horse effect ${ }^{2}$. From the various chemicals possibly carried by plastics debris, metal and metalloid elements are most used, by relative mass, in plastics ${ }^{3}$. Metals and metalloids are added as plasticizers, flame retardants, antioxidants, pigments, and more. ${ }^{4}$ (Throughout this paper, when the word "elements" is used, it is to mean metal and metalloid elements.) As other carbon-based particles are released in the environment, aging plastics debris can act as a support for biofilms or, in response to (photo)chemical oxidation of their surface functional groups, both biofilms and surface groups can adsorb metalloids ${ }^{5,6}$.

Metals and metalloids can be highly toxic when inadvertently consumed in aging plastic debris, as these elements are released from the sorbent under acidic digestive conditions (i.e., they become bioavailable through biological digestion processes). There is now clear evidence that chemicals associated with nanoplastics impact aquatic organisms' metabolism much more than the same pristine polymer without metal additives ${ }^{7}$. Measuring metals' relative bioavailability remains challenging, given their surface and/or core distribution in the plastics. From the surface to the core, element exchangeability and bioavailability decrease. However, after a long residence time in the environment, plastics can undergo highly oxidative conditions, which partly alter the surface of plastics and can induce the release of additives (i.e. elements). To evaluate the potential health risks induced by the ingestion of plastics by the biota, it is thus crucial to determine the total concentrations of each element and to discriminate between which elements are labile, and which are incorporated into 
plastic structures. However, the most important point is to determine which additives can be leached over time and become bioavailable for the biota.

The additive elements can be identified by measuring the depth distribution of element concentrations in the plastic by laser ablation (LA) inductively coupled plasma mass spectrometry (ICP-MS) ${ }^{8}$. However, only a few elements can be measured in plastic reference materials this way, and it is a time-consuming method. Another possibility is to perform a double extraction of elements: (i) from an acidic leaching to determine which elements are labile and (ii) from an acidic digestion to determine total element concentrations. Numerous studies have determined total metals concentrations in plastics by X-ray fluorescence spectrometry $(\mathrm{XRF})^{9-28}$, but this will be the first time for this joint approach consisting of coupling acidic leaching and digestion to ICP-MS or ICP-AES (atomic emission spectrometry) measurements. Our innovative approach aims to determine which elements are additive or adsorbed to the plastics, and their bioavailability to the biota.

\section{Material \& Methods}

\section{Geographic area and collection}

Fragments and pellets of plastic were collected in November 2018 on the beaches of Sainte Marie Bay in Guadeloupe (16²3'43.6"N 61 $\left.24^{\circ} 21.9^{\prime \prime} \mathrm{W}\right)$. This bay is exposed to the North Atlantic Gyre, which is known to be an area of plastic accumulation. The top $3 \mathrm{~cm}$ of sand composed of sargassum, sand, and plastics were manually collected. Size separation was performed using 2 sieves, with $1 \mathrm{~cm}$ and $2 \mathrm{~mm}$ grids. Microplastics and pellets from $2 \mathrm{~mm}$ to $1 \mathrm{~cm}$ were separated by visual morphologic aspects. Only microplastics were used in the present study. The collected microplastics were subdivided in 7 colours: Blue, Green, Orange, Red, Yellow, Black, Grey, and White. 


\section{Acidic leaching and acidic digestion}

Microplastics were first washed with deionized (DI) water under agitation to desorb (detach) any biofilms and natural organic matter residues that often occur with microplastics in the environment ${ }^{25}$. Then $1 \mathrm{~g}$ of each coloured microplastic was mixed with $0.1 \mathrm{M} \mathrm{HNO}_{3}$ (ultrapure grade) for $48 \mathrm{~h}$. Microplastics were then removed from the solution by filtration through a 0.2 $\mu \mathrm{m}$ filter. The solution $(<0.2 \mu \mathrm{m})$ was further analysed by ICP-MS. Finally, microplastic pieces were acid-digested using a multistep procedure with a microwave oven (UltraWAVE system from Millestone; $110^{\circ} \mathrm{C}$ for $10 \mathrm{~min}$, then $180^{\circ} \mathrm{C}$ for $10 \mathrm{~min}, 230^{\circ} \mathrm{C}$ for $20 \mathrm{~min}$ and $230^{\circ} \mathrm{C}$ for $\left.5 \mathrm{~min}\right)$. Prior to elemental analyses, samples were evaporated, dried, and then resolubilized with $\mathrm{HNO}_{3}$ at $0.37 \mathrm{M}$.

\section{Metal concentrations analysis}

Metal concentrations were measured by Inductively Coupled Plasma-Mass Spectrometry (ICP-MS) from Agilent Technologies (7700x Model, Agilent). The ICP-MS analyses introduced He gas into a collision cell to suppress any interference from Ar. All limits of quantification are presented in Table S1. The digestion process was validated using reference materials (ERM-EC 680 and ERM-EC 681) from the Joint Research Centre of the European Commission (JRC, Ispra, Italy) (see SI Section S1 for further information).

\section{Results and discussion}

In the present work, only microplastics from $2 \mathrm{~mm}$ to $1 \mathrm{~cm}$, a size that can be easily ingested by the marine and terrestrial biota, were studied ${ }^{31,32}$. Figure 1 presents the workflow and the hypotheses for the bioavailability of microplastic-associated elements. The percentage of elements released by the washing step was less than $0.1 \%$ of the total element concentrations (see Figure 1). This fraction of water-leached elements can be considered to be the most easily exchangeable fraction, and is thus negligible. The acidic leaching releases elements that can be desorbed from the microplastic surface. The $\mathrm{pH}$ conditions are aligned 
to those encountered in the stomach digestion of animals (i.e. bioavailable fraction by

101

102

103

104

105

106

107

108

109

110 ingestion route). The surface layer of environmentally-aged microplastics can be altered by wear and tear in the environment. For those altered microplastics, the acidic leached fraction represents both (i) the adsorbed environmental elements and (ii) the elements released from the microplastic alteration that were subsequently bound in the altered layer, namely a part of the additive metals. The acidic digestion is a total mineralization of the microplastic debris under extreme conditions (i.e., microwave process using concentrated acid and high temperatures). Such conditions are not environmentally relevant, but they facilitate the determination of less bioavailable metals. Microplastic debris is therefore providing a metal source rather than transfer vector. Based on this metal screening, acid digestion increases the bioavailable metals by four orders of magnitude (Figure 1), illustrating the importance of additives in the metal distribution in microplastics.

\section{Identification of the elements nature in the different coloured microplastics}

All elements can potentially be adsorbed on the microplastic surface through specific sites (i.e., carboxylic). Comparing the concentrations of elements determined after acidic leaching and total digestion can provide information on the additive or adsorbed origin of metals.

In Figure S2, the concentrations of (a) $\mathrm{Cu}$ (b) $\mathrm{Cd}$ (c) Zn (d) Pb (e) Ni (f) Ba (g) $\mathrm{Cr}$ (h) V and (i) As were compared for the acidic leaching and digestion, by subtracting the acid-leached concentrations from the total digestion concentrations ( $\mathrm{S}=$ [Digestion]-[Leaching]) for each colour (Figure 2 and $\mathrm{S} 1-2$ for $\mathrm{Al}$ ). High $\mathrm{S}$ values of this microplastics suggested that $\mathrm{S}$ could be used to distinguish between additive or adsorbed elements.

Due to their close behaviour, a linear relationship between Fe and Mn concentrations can be established. Only one sample is far from the linear relationship, so the relationship is good enough to determine the additive origin of some samples for $\mathrm{Fe}, \mathrm{Mn}$ and $\mathrm{Al}$ (SI Section S2 for 
further information). Thus, using Figure 2 and elements identified in the literature as additives

126 (Table S2 and S3), the additives elements can be identified as follows:

127

- Blue: Both $\mathrm{Cu}$ and Ba present large $\mathrm{S}$ values (814 and $2360 \mathrm{nmol} \mathrm{g}^{-1}$, respectively) in blue plastics compared to other colours of microplastics. This might be explained by the use of the inorganic blue pigments $\mathrm{BaCuSi}_{2} \mathrm{O}_{6}$ and $2 \mathrm{CuCO}_{3} \cdot \mathrm{Cu}(\mathrm{OH})_{2}$.

- Red: Ba and $V$ have high $S$ values (189 and $8 \mathrm{nmol} \mathrm{g}^{-1}$, respectively) in red plastics compared to other colours of microplastics. However, to our knowledge those elements are not used as red pigments, but $\mathrm{Ba}$ is a well-known filler in plastics. Unfortunately, very little information is available on $\mathrm{V}$ as an additive. However, trace elements were found in fly ash used for building materials, concrete modification, composite and polyester mortar, which might explain its presence as additive ${ }^{3}$.

- Green: Five elements present large $S$ values in the green microplastics: $\mathrm{Pb}(615.90$ nmol g$\left.{ }^{-1}\right), \mathrm{Cr}\left(485.68 \mathrm{nmol} \mathrm{g}^{-1}\right), \mathrm{Cu}\left(344.21 \mathrm{nmol} \mathrm{g}^{-1}\right), \mathrm{Ba}\left(141.40 \mathrm{nmol} \mathrm{g}^{-1}\right)$ and $\mathrm{Cd}(60.50$ $\left.\mathrm{nmol} \mathrm{g}^{-1}\right)$. The presence of $\mathrm{Cd}, \mathrm{Cr}$ and $\mathrm{Cu}$ should be explained by the use of green pigments, such as phthalocyanine green ( $\mathrm{Cu}$ organic complex), $\mathrm{Cu}\left(\mathrm{CH}_{3} \mathrm{COO}\right)_{2} \cdot \mathrm{H}_{2} \mathrm{O}$, $\mathrm{CuCO}_{3} \cdot \mathrm{Cu}(\mathrm{OH})_{2}, \mathrm{Cr}_{2} \mathrm{O}_{3} 2 \mathrm{H}_{2} \mathrm{O}$, and/or a mix of $\mathrm{CdS}$ and $\mathrm{Cr}_{2} \mathrm{O}_{3}$.

$\mathrm{Pb}$ and $\mathrm{Ba}$ are not used as green pigments, but they are used as yellow pigments as $\mathrm{Pb}_{3}\left(\mathrm{SbO}_{4}\right)_{2}, \mathrm{PbCrO}_{4}$ or $\mathrm{Pb}_{2} \mathrm{SnO}_{4}$ and $\mathrm{BaCrO}_{4}$, which likely explains their presence. Since $\mathrm{Sb}$ and $\mathrm{Sn}$ were not analysed in our study, it is impossible to know if $\mathrm{Pb}_{3}\left(\mathrm{SbO}_{4}\right)_{2}$ and $\mathrm{Pb}_{2} \mathrm{SnO}_{4}$ were used in this sample. The presence of $\mathrm{Cr}$ as an additive might confirm the use of $\mathrm{PbCrO}_{4}$ and $\mathrm{BaCrO}_{4}$.

The use of $\mathrm{Pb}$ and $\mathrm{Ba}$ for other properties can not also be excluded. $\mathrm{Pb}$ and $\mathrm{Ba}$ are also largely used in plastic formulations as heat stabilisers, antioxidants, UV stabilisers (Pb), and fillers $(\mathrm{Ba})$. The presence of $\mathrm{Cd}$ and $\mathrm{Pb}$ as additives in green microplastics from this sampling site was confirmed by El Hadri et al. ${ }^{8}$ using LC-ICP-MS (Table S4). 
- Orange: Five elements have large $S$ values in orange plastics: $\mathrm{Al}\left(122.82 \mu \mathrm{mol} \mathrm{g}^{-1}\right), \mathrm{Zn}$ $\left(8820.68 \mathrm{nmol} \mathrm{g}{ }^{-1}\right), \mathrm{Cd}\left(426.48 \mathrm{nmol} \mathrm{g}{ }^{-1}\right), \mathrm{Ba}\left(68.32 \mathrm{nmol} \mathrm{g}^{-1}\right)$, and $\mathrm{V}\left(53.20 \mathrm{nmol} \mathrm{g}^{-1}\right)$. The presence of $\mathrm{Cd}$ might be explained by the use of the orange pigment CdS. The presence of $\mathrm{Zn}, \mathrm{Ba}$ and $\mathrm{V}$ might be explained either by their use as yellow pigments or for other properties. Other yellow pigments include $\left.\mathrm{BiVO}_{4}, \mathrm{~K}_{2} \mathrm{O} 4 \mathrm{ZnCrO} \mathrm{nC}_{4} \mathrm{O}\right)_{3}, \mathrm{BaCrO}_{4}$. However, $\mathrm{Ba}$ and $\mathrm{Zn}$ are also well-known fillers and $\mathrm{Zn}$ is also a flame retardant. To our knowledge, no common orange, red or yellow pigments contain Al. Thus, Al's presence in this sample as an additive is likely due to its use as flame retardant. Note that El Hadri et al. ${ }^{8}$ showed that Cd was present as an additive in orange microplastics by LC-ICP-MS analysis (Table S4).

- Grey and Black: Five elements have large $S$ values in grey and black plastics: $\mathrm{Cu}$ (402.12 nmol g $\left.{ }^{-1}\right), \mathrm{Pb}\left(180.13 \mathrm{nmol} \mathrm{g}^{-1}\right), \mathrm{Cr}\left(174.77 \mathrm{nmol} \mathrm{g}^{-1}\right), \mathrm{Mn}\left(75.72 \mathrm{nmol} \mathrm{g}^{-1}\right)$ and Cd $\left(49.77 \mathrm{nmol} \mathrm{g}^{-1}\right)$. Large $\mathrm{Mn}$ and Cd concentrations could be explained by the use of $\mathrm{Cd}-\mathrm{Mn}$ pigments. The presence of $\mathrm{Cu}, \mathrm{Pb}$ and $\mathrm{Cr}$ as additives are either explained by their use as a mix of different pigments to obtain the black colour, or their use for properties other than pigments in this sample. Note that the presence of $\mathrm{Pb}$ as an additive was also highlighted by El Hadri et al. ${ }^{8}$ in grey microplastics from the same field site analysed by LC-ICP-MS (Table S4).

- Yellow and White: No element has a large $S$ in yellow or white microplastics. Therefore, no additive elements are highlighted in these microplastics.

\section{Release of additives}

171 The $S$ calculation helped to identify which elements are additives in the microplastics we collected from the Guadeloupe beaches. However, this method does not give any

173 information about the source of the acid-leached elements: are they coming from the

174 environment or are they coming from the alteration of microplastics? Looking at the

$175[$ metal $] /[\text { metal }]_{\text {acidic leaching }}$ and [metal]/[metal $]_{\text {acidic digestion }}$ ratio for metals identified as additives in 
the orange and grey and black samples (see Section 3.1), two different behaviours are exhibited (Figure 3). $\mathrm{Cu}, \mathrm{Pb}, \mathrm{Cr}$ and $\mathrm{Cd}$ exhibit similar [metal]/[metal] $]_{\text {acidic leaching }}$ and

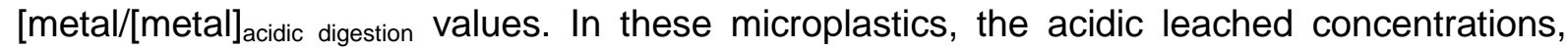
namely adsorbed $\mathrm{Cu}, \mathrm{Pb}, \mathrm{Cr}$ and $\mathrm{Cd}$, may therefore originate from the alteration of plastics and the subsequent adsorption of released additives.

In contrast, $\mathrm{Mn}, \mathrm{Al}$ and $\mathrm{Zn}$ present larger [metal]/[metal $]_{\text {acidic }}$ digestion values than $\left[\right.$ metal] $/[\text { metal }]_{\text {acidic leaching }}$ values. These additives are therefore either not leached in significant amounts, or they are progressively released from the plastic surface to the external environment. All these elements are known as oligo-elements. Manganese is usually used as $\mathrm{Mn}(\mathrm{IV})$ oxide for grey pigment in plastic formulations. Microorganisms are able to reduce $\mathrm{Mn}(\mathrm{IV})$ to $\mathrm{Mn}(\mathrm{II})$, releasing the $\mathrm{Mn}$ from the plastic to the solution. Aluminium and $\mathrm{Zn}$ as additives are also solubilized and potentially consumed by the biota as oligo-elements, disappearing from the system as a consequence. By contrast $\mathrm{Pb}, \mathrm{Cr}$ and $\mathrm{Cd}$ are nonessential elements for living organisms and should therefore not be preferentially consumed.

\section{Bioavailability of adsorbed and additive elements}

Numerous studies have shown that plastics are ingested accidentally by animals. Plastics can injure animals through both the plastic itself, and through pollutants adsorbed on the plastic surface that can be released by digestion processes (conditions similar to acidic leaching). If the largest concentrations measured in the plastics correspond to additive elements, additive elements are less (or not) released by acid than adsorbed elements. Ecotoxic parameters only discuss acidic leached concentrations of elements that may be dangerous to animals due to their release in acidic stomach conditions.

The ECOTOX (https://cfpub.epa.gov/ecotox/search.cfm) database contains the Lowest Observed Effect Concentrations (LOEC [mg (kg-food $\left.)^{-1}\right]$ ) that have been determined for Fe, $\mathrm{Cu}, \mathrm{Zn}, \mathrm{As}, \mathrm{Cd}$ and $\mathrm{Pb}$ for several fish (Table S5). Note that LOEC were determined for 
acute tests by ingesting one dose of each element. Concentrations measured after acidic leaching for $\mathrm{Fe}, \mathrm{Cu}, \mathrm{Zn}, \mathrm{As}$ and $\mathrm{Pb}$ are lower than the LOEC (minimal and maximal values) for all microplastics samples (Table S5). Cadmium concentrations in the blue and grey and black microplastics were below the LOEC minimal value but higher for the green, orange, red, yellow and white microplastics. However, fish do not only eat plastics $(100 \%$ food $\neq$ $100 \%$ plastic); they tend to ingest the plastic along with real food. From Cd concentrations measured in the acidic leaching and for an LOEC of $0.07 \mathrm{mg}(\mathrm{kg} \mathrm{food})^{-1}$, it is possible to calculate the maximal percentage of plastic in food for which the LOEC is attained. The percentage of microplastic in the fish's food has be higher than $72 \%$ (Green), $71 \%$ (White), 24\% (Yellow), 21\% (Orange) and 16\% (Red) to observe effects due to Cd from plastics. These percentages show that it is highly improbable that fish will eat sufficient plastics by accident to present a danger for them.

Our results suggest that our microplastic samples are not very dangerous for fish, when ingested in one dose. However, here, we only studied the possible danger posed by (i) the ingestion of a single dose of metal adsorbed by plastics, whereas chronic ingestion could also be a potential danger for biota. We did not consider the potential synergetic health effects of the elements being in mixtures in plastics. As well, plastics themselves can hurt ecosystems. It would thus be interesting to study the effects of chronic ingestion of metals adsorbed onto plastics and verify their toxicity or lack of it.

\section{Conclusion}

It is crucial to determine the origin of elements contained in plastic debris, since the response of additives and sorbed metalloids to physico-chemical conditions can vary. In our study, we provided a new and simple method to determine the additive versus sorbed elements in microplastics. This method consists of measuring and comparing the concentrations of elements released from two processes: acidic leaching and total digestion. Using this 
method, a large number of element concentrations can be determined simultaneously. Our method also determines the bioavailable elements for living organisms.

The colour of the microplastic debris of the North Atlantic Gyre that is deposited on

Guadeloupe beaches depends on the heterogeneous elements it contains. Several elements were probably used as pigments ( $\mathrm{Cd}, \mathrm{Cu}, \mathrm{Cr}$, and possibly $\mathrm{Pb}, \mathrm{Ba}$, and $\mathrm{V})$. When plastics are altered by the addition of these elements, the additives seem to be mobile. Only Cd seems to be a danger when ingested by fish. Considering the percentage of plastic potentially ingested by fish, Cd levels do not seem to reach the LOEC. However, further research is needed to determine if microplastics and associated elements affect the health of the biota, and what effects the chronic consumption of plastics with additive elements might have.

\section{Acknowledgments}

237 This work was supported by the French National Research Agency (ANR) through the program PLASTI-SCARE. We are grateful to the environmental geochemical analytical platform of Geosciences Rennes (GrEEN). We thank Martine Bouhnik Le Coz for her work on the acid digestions.

\section{Bibliography}

1 R. Geyer, J. R. Jambeck and K. L. Law, Sci. Adv., 2017, 3, e1700782.

2 H. Bouwmeester, P. C. H. Hollman and R. J. B. Peters, Environ. Sci. Technol., 2015, 49, 8932-8947.

3 G. Wypych, in Handbook of Fillers (Fourth Edition), ed. G. Wypych, ChemTec Publishing, 2016, pp. 13-266.

4 J. N. Hahladakis, J. Hazard. Mater., 2018, 21.

5 C. M. Rochman, B. T. Hentschel and S. J. Teh, PLoS ONE, 2014, 9, e85433.

6 L. A. Holmes, A. Turner and R. C. Thompson, Environ. Pollut., 2012, 160, 42-48.

7 M. Baudrimont, A. Arini, C. Guégan, Z. Venel, J. Gigault, B. Pedrono, J. Prunier, L. Maurice, A. Ter Halle and A. Feurtet-Mazel, Environ. Sci. Pollut. Res., 2020, 27, 37463755.

8 H. El Hadri, J. Gigault, S. Mounicou, B. Grassl and S. Reynaud, Mar. Pollut. Bull., 2020, 160, 111716.

9 A. Turner, Mar. Pollut. Bull., 2016, 111, 136-142.

10M. Carbery, G. R. MacFarlane, W. O'Connor, S. Afrose, H. Taylor and T. Palanisami, Mar. Pollut. Bull., 2020, 152, 110914. 
11J. Deng, P. Guo, X. Zhang, H. Su, Y. Zhang, Y. Wu and Y. Li, Mar. Pollut. Bull., 2020, 159, 111482.

12S. Fernandes, S. Farzaneh and L. I. Bendell, Mar. Pollut. Bull., 2020, 159, 111479.

13W. Li, H.-S. Lo, H.-M. Wong, M. Zhou, C.-Y. Wong, N. F.-Y. Tam and S.-G. Cheung, Mar. Pollut. Bull., 2020, 153, 110977.

14A. I. S. Purwiyanto, Y. Suteja, Trisno, P. S. Ningrum, W. A. E. Putri, Rozirwan, F. Agustriani, Fauziyah, M. R. Cordova and A. F. Koropitan, Mar. Pollut. Bull., 2020, 158, 111380.

15T. Y. Suman, W.-G. Li, S. Alif, V. R. P. Faris, D. J. Amarnath, J.-G. Ma and D.-S. Pei, Environ. Sci. Eur., 2020, 32, 110.

16A. T. Ta and S. Babel, Chemosphere, 2020, 257, 127234.

17I. Acosta-Coley, D. Mendez-Cuadro, E. Rodriguez-Cavallo, J. de la Rosa and J. OliveroVerbel, Mar. Pollut. Bull., 2019, 139, 402-411.

18J. Prunier, L. Maurice, E. Perez, J. Gigault, A.-C. Pierson Wickmann, M. Davranche and A. ter Halle, Environ. Pollut., 2019, 245, 371-379.

19S. Dobaradaran, T. C. Schmidt, I. Nabipour, N. Khajeahmadi, S. Tajbakhsh, R. Saeedi, M. Javad Mohammadi, M. Keshtkar, M. Khorsand and F. Faraji Ghasemi, Waste Manag., 2018, 78, 649-658.

20J. Maršić-Lučić, J. Lušić, P. Tutman, D. Bojanić Varezić, J. Šiljić and J. Pribudić, Mar. Pollut. Bull., 2018, 137, 231-236.

21 M. C. Vedolin, C. Y. S. Teophilo, A. Turra and R. C. L. Figueira, Mar. Pollut. Bull., 2018, 129, 487-493.

22J. Wang, J. Peng, Z. Tan, Y. Gao, Z. Zhan, Q. Chen and L. Cai, Chemosphere, 2017, 171, 248-258.

23V. J. Noik, P. M. Tuah, L. Seng and M. Sakari, 2015, 6.

24E. Nakashima, A. Isobe, S. Kako, T. Itai and S. Takahashi, Environ. Sci. Technol., 2012, 46, 10099-10105.

25K. Ashton, L. Holmes and A. Turner, Mar. Pollut. Bull., 2010, 60, 2050-2055.

26H. Aslam, T. Ali, M. M. Mortula and A. G. Attaelmanan, Mar. Pollut. Bull., 2020, 150, 110739.

27M. Filella and A. Turner, Front. Environ. Sci., 2018, 6, 1.

28I. Martins, Y. Rodríguez and C. K. Pham, Mar. Pollut. Bull., 2020, 156, 111270.

290. H. Fred-Ahmadu, O. O. Ayejuyo and N. U. Benson, Data Brief, 2020, 31, 105755.

30B. Munier and L. I. Bendell, PLOS ONE, 2018, 13, e0191759.

31P. Wardrop, J. Shimeta, D. Nugegoda, P. D. Morrison, A. Miranda, M. Tang and B. O. Clarke, Environ. Sci. Technol., 2016, 50, 4037-4044.

32L. Bradney, H. Wijesekara, K. N. Palansooriya, N. Obadamudalige, N. S. Bolan, Y. S. Ok, J. Rinklebe, K.-H. Kim and M. B. Kirkham, Environ. Int., 2019, 131, 104937. 
$312{ }^{*}$ Corresponding authors: julien.gigault@takuvik.ulaval.ca and charlotte.catrouillet@univ313 rennes $1 . \mathrm{fr}$ 
317 Quantitative analyses were performed using a conventional external calibration procedure (7 318 external standard multi-element solutions were purchased from Inorganic Venture, USA). A $319300 \mathrm{ppb}$ mixed solution of rhodium and rhenium was injected with the sample in-line in the 320 nebulizer. This solution was used as an internal standard for all measured samples, to 321 correct any instrumental drift and matrix effects. Calibration curves were calculated based on 322 the intensity ratios between the internal standard and the analysed elements. An SLRS-6 323 water standard was used to check the accuracy of the measurement procedure.

324 The matrix of reference materials (ERM-EC 680 and ERM-EC 681) is composed of 325 polyethylene supplemented with various concentrations of inorganic additives including As, $326 \mathrm{Cd}, \mathrm{Cr}, \mathrm{Pb}$ and $\mathrm{Zn}$. Concentrations were validated for As (-0.56 and 9.26\% of error), Cd (3271.04 and $0.82 \%), \operatorname{Cr}(-0.8$ and $3.16 \%$ of error), $\mathrm{Pb}(10.19$ and $3.54 \%$ of error) and $\mathrm{Zn}(-0.68$ 328 and $-7.75 \%$ of error).

Table 1: Quantification limit of the ICP-MS.

\begin{tabular}{|l|l|l|l|l|l|l|l|l|}
\hline \multirow{2}{*}{ Element } & \multirow{2}{*}{ Isotope } & Mode & $<1000$ & $<100 \mathrm{ppb}$ & $<10 \mathrm{ppb}$ & $<1 \mathrm{ppb}$ & $<0,5 \mathrm{ppb}$ & $<0,1 \mathrm{ppb}$ \\
\cline { 5 - 10 } & & & $\mathrm{ppb}$ & $\mathrm{ppb}$ & $\mathrm{ppb}$ & $\mathrm{ppb}$ & $\mathrm{ppb}$ & $\mathrm{ppb}$ \\
\hline $\mathrm{Al}$ & 27 & No Gas & $3 \%$ & $5 \%$ & $5 \%$ & $5 \%$ & $5 \%$ & $10 \%$ \\
\hline $\mathrm{V}$ & 51 & $\mathrm{He}$ & $3 \%$ & $5 \%$ & $5 \%$ & $5 \%$ & $5 \%$ & $10 \%$ \\
\hline $\mathrm{Cr}$ & 52 & $\mathrm{He}$ & $3 \%$ & $5 \%$ & $5 \%$ & $5 \%$ & $5 \%$ & $10 \%$ \\
\hline $\mathrm{Cr}$ & 53 & $\mathrm{He}$ & $3 \%$ & $5 \%$ & $5 \%$ & $5 \%$ & $5 \%$ & $10 \%$ \\
\hline $\mathrm{Mn}$ & 55 & $\mathrm{He}$ & & $3 \%$ & $3 \%$ & $5 \%$ & $5 \%$ & $10 \%$ \\
\hline $\mathrm{Fe}$ & 56 & $\mathrm{He}$ & $3 \%$ & $5 \%$ & $5 \%$ & $10 \%$ & & \\
\hline $\mathrm{Fe}$ & 57 & $\mathrm{He}$ & $3 \%$ & $5 \%$ & $5 \%$ & $10 \%$ & & \\
\hline $\mathrm{Co}$ & 59 & $\mathrm{He}$ & & $3 \%$ & $3 \%$ & $5 \%$ & $5 \%$ & $10 \%$ \\
\hline $\mathrm{Ni}$ & 60 & $\mathrm{He}$ & & $3 \%$ & $3 \%$ & $5 \%$ & $5 \%$ & $10 \%$ \\
\hline $\mathrm{Ni}$ & 62 & $\mathrm{He}$ & & $3 \%$ & $3 \%$ & $5 \%$ & $5 \%$ & $10 \%$ \\
\hline $\mathrm{Cu}$ & 65 & $\mathrm{He}$ & $3 \%$ & $3 \%$ & $3 \%$ & $5 \%$ & $5 \%$ & $10 \%$ \\
\hline
\end{tabular}




\begin{tabular}{|l|l|l|l|l|l|l|l|l|}
\hline Zn & 66 & No Gas & & $3 \%$ & $3 \%$ & $5 \%$ & $5 \%$ & $10 \%$ \\
\hline Zn & 66 & He & $3 \%$ & $3 \%$ & $3 \%$ & $5 \%$ & $5 \%$ & $10 \%$ \\
\hline As & 75 & He & & $3 \%$ & $3 \%$ & $5 \%$ & $5 \%$ & $10 \%$ \\
\hline Cd & 111 & No Gas & & $3 \%$ & $3 \%$ & $5 \%$ & $5 \%$ & $10 \%$ \\
\hline $\mathrm{Ba}$ & 138 & No Gas & $3 \%$ & $3 \%$ & $3 \%$ & $3 \%$ & $5 \%$ & $10 \%$ \\
\hline $\mathrm{Pb}$ & 208 & No Gas & & & $3 \%$ & $3 \%$ & $5 \%$ & $10 \%$ \\
\hline
\end{tabular}


332 Due to their similar chemical behaviour, Fe and $\mathrm{Mn}$ concentrations in water are usually 333 related by a linear relationship. Interestingly, Fe and Mn also show this linear relationship in 334 all the coloured microplastics, except for the grey and black microplastics (Figure S1a). 335 There are three factors that lead us to state that Fe and $\mathrm{Mn}$ are present as sorbent elements 336 in all samples, except for the grey and black sample: (i) to our knowledge, Fe is used as an 337 additive only as an inorganic pigment (Table S1 and 2), (ii) $\mathrm{Mn}$ is used only as an inorganic 338 pigment for the grey colour (Table S1 and 2), and (iii) Fe and Mn concentrations are linearly 339 linked. Similarly, a linear relationship is highlighted between Al and Mn concentrations, 340 except for the orange microplastics (Figure S1b and c). Both microplastics samples (grey 341 and black for $\mathrm{Mn}$ and orange for $\mathrm{Al}$ ) could, therefore, be additives. Comparing the $\mathrm{S}$ values of $342 \mathrm{Al}, \mathrm{Mn}$ and Fe (Figure 2a)), those two samples (grey and black for $\mathrm{Mn}$ and orange for $\mathrm{Al}$ ) 343 present high S values. We can thus identify elements as additives based on their $S$ values. 

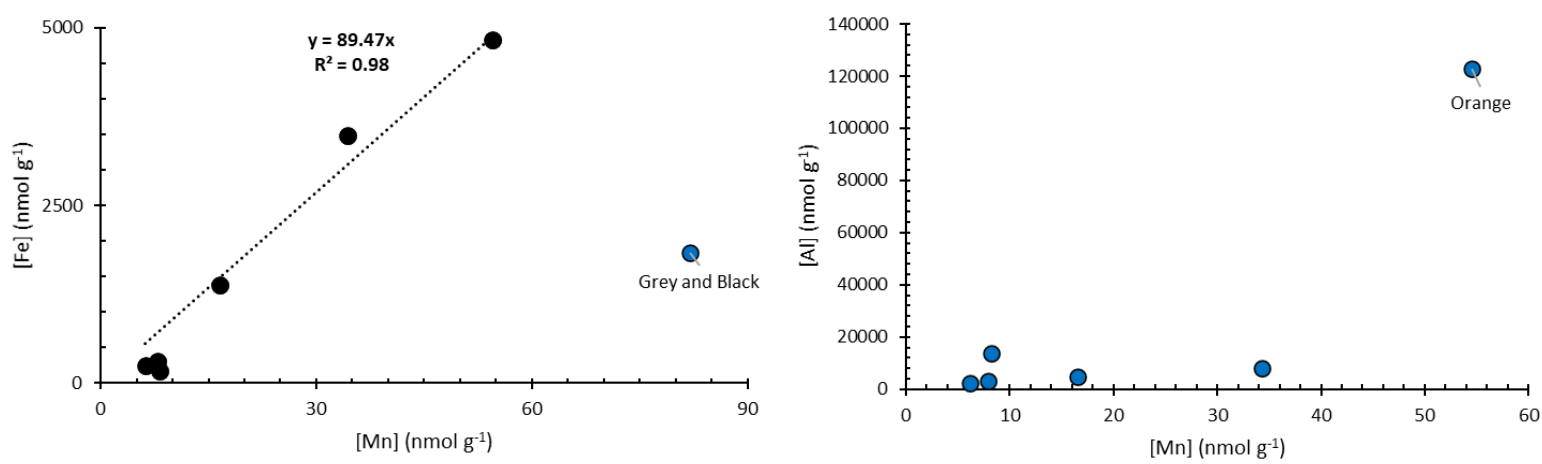

a)

b)
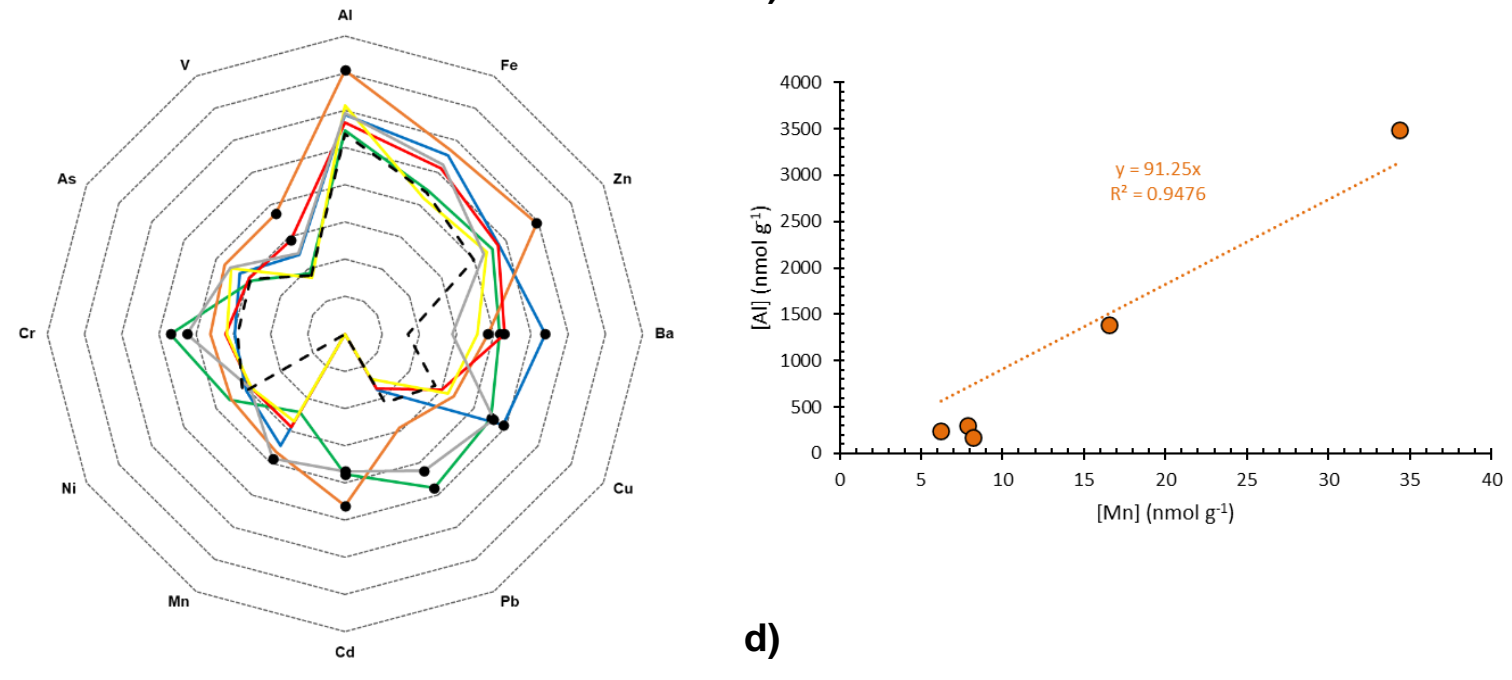

d)

347 microplastics and (c) without the orange microplastics. d) $S$ values obtained from acidic leaching and digestion for $348 \mathrm{Al}, \mathrm{Fe}, \mathrm{Zn}, \mathrm{Ba}, \mathrm{Cu}, \mathrm{Pb}, \mathrm{Cd}, \mathrm{Mn}, \mathrm{Ni}, \mathrm{Cr}, \mathrm{As}$ and $\mathrm{V}$ elements; high $\mathrm{S}$ values indicate these are additives in 349 microplastics. 

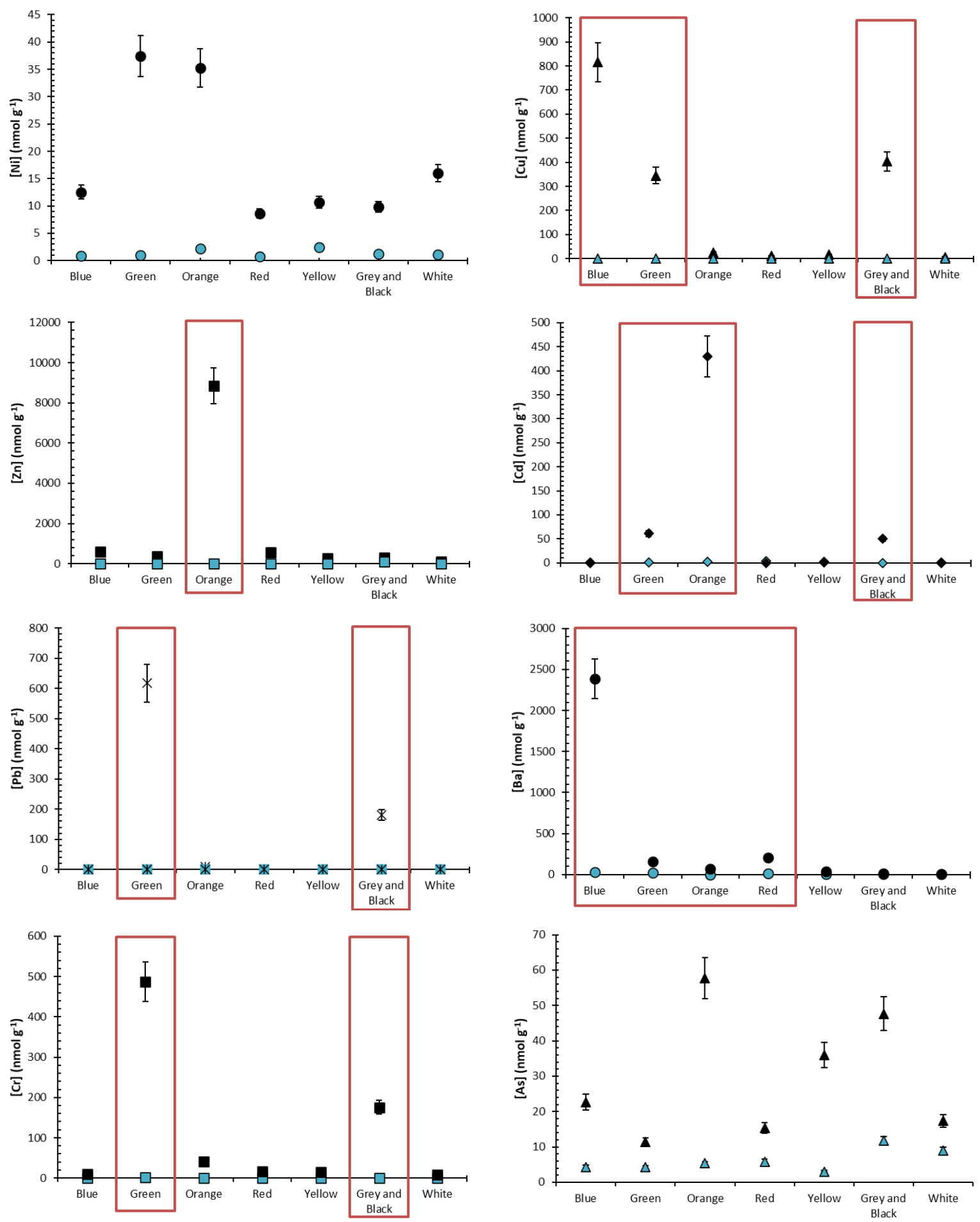


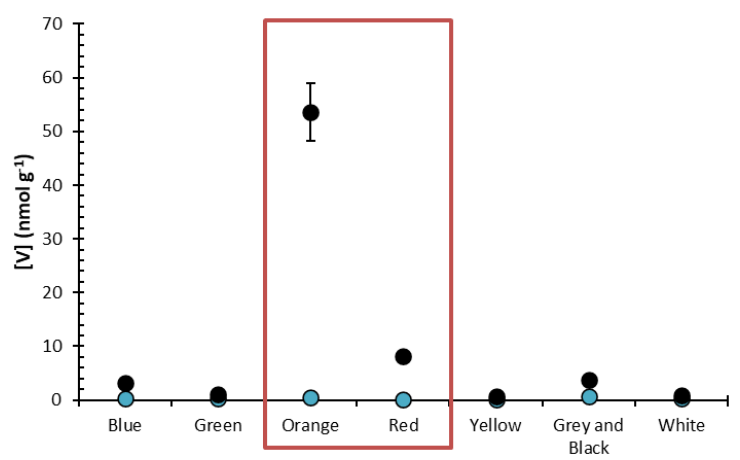

- Acidic digestion o Acidic leaching

350 Figure 2: Element concentrations measured in the acidic leachate after total acidic digestion. Red rectangles 351 highlight the high differences in extraction concentrations. 
354 Table 2: Summary of elements that are used as pigments. Most of the data comes from the Internet site 355 https://colourlex.com/pigments/pigments-colour/.

\begin{tabular}{|c|c|c|}
\hline Colour & Name of the pigment & Composition \\
\hline Blue & $\begin{array}{l}\text { Han Blue } \\
\text { Egyptian blue } \\
\text { Blue Verditer } \\
\text { Manganese Blue } \\
\text { Vivianite } \\
\text { Cerulean Blue } \\
\text { Prussian Blue } \\
\text { Smalt } \\
\text { Azurite } \\
\text { Cobalt Blue } \\
\text { Ultramarine }\end{array}$ & $\begin{array}{l}\mathrm{Yln}_{1-\mathrm{x}} \mathrm{Mn}_{\mathrm{x}} \mathrm{O}_{3} \\
\mathrm{BaCuSi}_{2} \mathrm{O}_{6} \\
\mathrm{CaCuSi}_{4} \mathrm{O}_{10} \\
2 \mathrm{CuCO}_{3} \cdot \mathrm{Cu}(\mathrm{OH})_{2} \\
\mathrm{BaMnO}_{4} \cdot \mathrm{BaSO}_{4} \\
\mathrm{Fe}_{3}\left(\mathrm{PO}_{4}\right)_{2} \cdot 8 \mathrm{H}_{2} \mathrm{O} \\
\mathrm{CoSnO} \\
\mathrm{Fe}_{4}\left[\mathrm{Fe}(\mathrm{CN})_{6}\right]_{3} \cdot \mathrm{xH}_{2} \mathrm{O} \\
\text { contain } \mathrm{Co} \\
2 \mathrm{CuCO}_{3} \cdot \mathrm{Cu}(\mathrm{OH})_{2} \\
\mathrm{CoAl}_{2} \mathrm{O}_{4} \\
\mathrm{Na}_{7} \mathrm{Al}_{6} \mathrm{Si}_{6} \mathrm{O}_{24} \mathrm{~S}_{3}\end{array}$ \\
\hline Red & $\begin{array}{l}\text { Pompeiian Red } \\
\text { Chrome Red } \\
\text { Cadmium Red } \\
\text { Red Lead } \\
\text { Red Ochre } \\
\text { Vermilion } \\
\text { Realgar }\end{array}$ & $\begin{array}{l}\text { Iron oxide }+ \text { clay and quartz } \\
\mathrm{PbO} \mathrm{PbCrO}_{4} \\
\mathrm{Cd}(\mathrm{S}, \mathrm{Se}) \\
\mathrm{Pb}_{3} \mathrm{O}_{4} \\
\mathrm{Hematite} \text { (Iron oxide) } \\
\mathrm{HgS} \\
\mathrm{As}_{4} \mathrm{~S}_{4}\end{array}$ \\
\hline Yellow & $\begin{array}{l}\text { Raw Sienna } \\
\text { Bismuth Vanadate } \\
\text { Yellow } \\
\text { Zinc Yellow } \\
\text { Lemon Yellow } \\
\text { Cobalt Yellow } \\
\text { Naples Yellow } \\
\text { Cadmium Yellow } \\
\text { Yellow Ochre } \\
\text { Orpiment } \\
\text { Chrome Yellow }\end{array}$ & $\begin{array}{l}\text { Iron oxide }+ \text { small amounts of } \mathrm{Mn} \\
\text { oxides } \\
\mathrm{BiVO}_{4} \\
\mathrm{~K}_{2} \mathrm{O} 4 \mathrm{ZnCrO}{ }_{4}\left(\mathrm{H}_{2} \mathrm{O}\right)_{3} \\
\mathrm{BaCrO}_{4} \\
\mathrm{~K}_{3}\left[\mathrm{Co}\left(\mathrm{NO}_{2}\right)_{6}\right] \\
\mathrm{Pb}_{3}\left(\mathrm{SbO}_{4}\right)_{2} \\
\mathrm{CdS} \\
\text { Iron oxides } \\
\mathrm{As}_{2} \mathrm{~S}_{3} \\
\mathrm{PbCrO}_{4}\end{array}$ \\
\hline
\end{tabular}




\begin{tabular}{|c|c|c|}
\hline & Lead-Tin Yellow & $\mathrm{Pb}_{2} \mathrm{SnO}_{4}$ \\
\hline Green & $\begin{array}{l}\text { Phthalocyanine Green } \\
\text { Cobalt Titanate Green } \\
\text { Verdigris } \\
\text { Green Earth } \\
\text { Malachite } \\
\text { Viridian } \\
\text { Emerald Green } \\
\text { Cadmium Green }\end{array}$ & $\begin{array}{l}\text { Cu organic complex } \\
\mathrm{Co}_{2} \mathrm{TiO}_{4} \\
\mathrm{Cu}\left(\mathrm{CH}_{3} \mathrm{COO}\right)_{2} \cdot \mathrm{H}_{2} \mathrm{O} \\
\mathrm{K}\left[\left(\mathrm{Al}, \mathrm{Fe}^{\text {III }}\right),\left(\mathrm{Fe}{ }^{\prime \prime}, \mathrm{Mg}\right]\left(\mathrm{AlSi}_{3}, \mathrm{Si}_{4}\right) \mathrm{O}_{10}(\mathrm{OH})_{2}\right. \\
\mathrm{CuCO}_{3} \cdot \mathrm{Cu}(\mathrm{OH})_{2} \\
\mathrm{Cr}_{2} \mathrm{O}_{3} \cdot 2 \mathrm{H}_{2} \mathrm{O} \\
3 \mathrm{Cu}(\mathrm{AsO})_{2} \cdot \mathrm{Cu}\left(\mathrm{CH}_{3} \mathrm{COO}\right)_{2} \\
\text { mix of } \mathrm{CdS} \text { and } \mathrm{Cr}_{2} \mathrm{O}_{3}\end{array}$ \\
\hline Orange & $\begin{array}{l}\text { Antimony Orange } \\
\text { Cadmium Orange } \\
\text { Chrome Orange } \\
\text { Orange Ochre } \\
\text { Realgar }\end{array}$ & $\begin{array}{l}2 \mathrm{Sb}_{2} \mathrm{~S}_{3} \cdot \mathrm{Sb}_{2} \mathrm{O}_{3} \\
\mathrm{CdS} \\
\mathrm{PbO} \cdot \mathrm{PbCrO}_{4} \\
\text { Iron oxides } \\
\text { AsS, } \mathrm{As}_{2} \mathrm{~S}_{2} \text { or } \mathrm{As}_{4} \mathrm{~S}_{4}\end{array}$ \\
\hline Grey and Black & $\begin{array}{l}\text { Spinel black } \\
\text { Manganese Black }\end{array}$ & $\begin{array}{l}\mathrm{MnFe}_{2} \mathrm{O}_{4} \\
\text { Manganese and Iron oxides }\end{array}$ \\
\hline White & $\begin{array}{l}\text { Titanium Dioxide White } \\
\text { Calcite } \\
\text { Zinc White } \\
\text { Lead White }\end{array}$ & $\begin{array}{l}\mathrm{TiO}_{2} \\
\mathrm{CaCO}_{3} \\
\mathrm{ZnO} \\
2 \mathrm{PbCO}_{3} \cdot \mathrm{Pb}(\mathrm{OH})_{2}\end{array}$ \\
\hline
\end{tabular}

\begin{tabular}{|c|c|}
\hline Element & Use \\
\hline Al & $\begin{array}{l}\text { - Special effects (such as fluorescence). } \\
\text { - Flame retardant }\end{array}$ \\
\hline Zn & $\begin{array}{l}\text { - Inorganic pigments } \\
\text { - Fillers } \\
\text { - Flame retardant as zinc borate }\end{array}$ \\
\hline As & - Biocides \\
\hline $\mathrm{Fe}$ & - Inorganic pigments \\
\hline$\overline{M n}$ & - Inorganic pigments (cadmium-manganese based possible) \\
\hline $\mathrm{Cu}$ & - Special effect (such as fluorescence) \\
\hline $\mathrm{Cr}$ & - Inorganic pigments \\
\hline $\mathrm{Ba}$ & - Fillers \\
\hline $\mathbf{P b}$ & $\begin{array}{l}\text { - Stabilisers, Antioxidants and UV stabilisers } \\
\text { - Heat stabilisers } \\
\text { - Inorganic pigments } \\
\text { - Special effect (such as fluorescence) }\end{array}$ \\
\hline Cd & $\begin{array}{l}\text { - Stabilisers, Antioxidants and UV stabilisers } \\
\text { - Heat stabilisers }\end{array}$ \\
\hline
\end{tabular}


359 Table 4: Summary of the results obtained by El Hadri (2020) from microplastics collected at the same sampling 360 site measured by LC-ICP-MS. Two behaviours were identified in the samples: additive (Add) and sorbed (Sor)

361

\begin{tabular}{|l|ccccccc|}
\hline Colour & Orange & White & Yellow & Blue & Beige & Green & Grey \\
\hline Cd & Add & Add/Sor & Add/Sor & Sor & Add & Add & Sor \\
As & Sor & Sor & Sor & Sor & Sor & Sor & Sor \\
Zn & Sor & Sor & Add & Add & Add & Add & Sor \\
$\mathrm{Pb}$ & S & Sor & S & Sor & Sor & Add & Add \\
\hline
\end{tabular}

362 
364 (LOEC) determined for each element in this study. LOEC data is from the Internet database:

365 https://cfpub.epa.gov/ecotox/

366

\begin{tabular}{|c|c|c|c|c|c|c|c|}
\hline & & $\mathrm{Fe}$ & $\mathrm{Cu}$ & $\mathrm{Zn}$ & As & $\mathrm{Cd}$ & $\mathrm{Pb}$ \\
\hline Blue & {$\left[\mathrm{mg}(\mathrm{kg} \mathrm{pl.})^{-1}\right]$} & 0.87 & 0.09 & 0.51 & 0.25 & 0.05 & 0.18 \\
\hline Green & [mg (kg pl. $\left.)^{-1}\right]$ & 1.02 & 0.06 & 0.56 & 0.24 & 0.10 & 0.27 \\
\hline Orange & [mg (kg pl. $\left.)^{-1}\right]$ & 1.94 & 0.06 & 0.57 & 0.24 & 0.33 & 0.04 \\
\hline Red & [mg (kg pl. $\left.)^{-1}\right]$ & 0.22 & 0.04 & 0.32 & 0.37 & 0.42 & 0.00 \\
\hline Yellow & [mg (kg pl. $)^{-1}$ ] & 0.52 & 0.04 & 0.38 & 0.12 & 0.29 & 0.04 \\
\hline Grey and Black & [mg (kg pl. $\left.)^{-1}\right]$ & 3.29 & 0.08 & 7.41 & 0.68 & 0.03 & 0.15 \\
\hline White & [mg (kg pl. $\left.)^{-1}\right]$ & 0.38 & 0.07 & 0.43 & 0.57 & 0.10 & 0.00 \\
\hline LOEC min & {$\left[\mathrm{mg}(\mathrm{kg} \text { food })^{-1}\right]$} & 560 & 0.28 & 100 & 28 & 0.07 & 7.20 \\
\hline LOEC max & {$\left[\mathrm{mg}(\mathrm{kg} \mathrm{food})^{-1}\right]$} & 560 & 1780 & 5926 & 732 & 615 & 802.92 \\
\hline
\end{tabular}

367

368

369

370

371

372

373

374

375

376

377 
Figures:

\section{additive, adsorbed, and bioavailable}

Charlotte Catrouillet ${ }^{\mathrm{a}^{\star}}$, Mélanie Davranche ${ }^{\mathrm{a}}$ Imane Khatib $^{\mathrm{a}}$, Corentin Fauny ${ }^{\mathrm{a}}$, Aurélie Wahl ${ }^{\mathrm{a}}$, Julien Gigault ${ }^{\mathrm{a}, \mathrm{b}^{*}}$.

390 *Corresponding authors: julien.gigault@takuvik.ulaval.ca and charlotte.catrouillet@univ391 rennes $1 . f r$ 


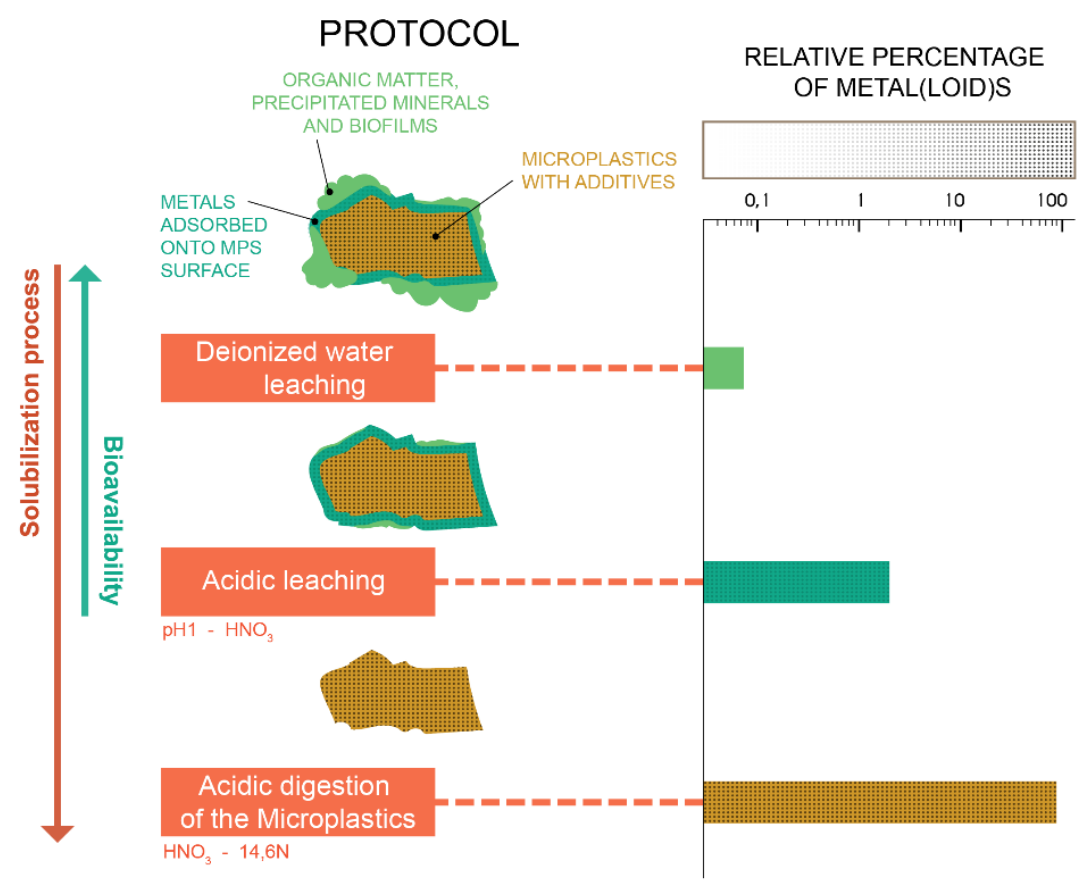

HYPOTHESIS

- Easily exchangeable

trace metals

- Highly bioavailable

Release of adsorbed metals

onto plastic surface

- Bioavailable under

acidic conditions

(digestive condition)

- Release of additive metals

in the dissolved phase

- Less bioavailable (released over long time, or in extreme conditions)

393

394 Figure 3: Protocol developed in our study and linked hypothesis

395

396

397 


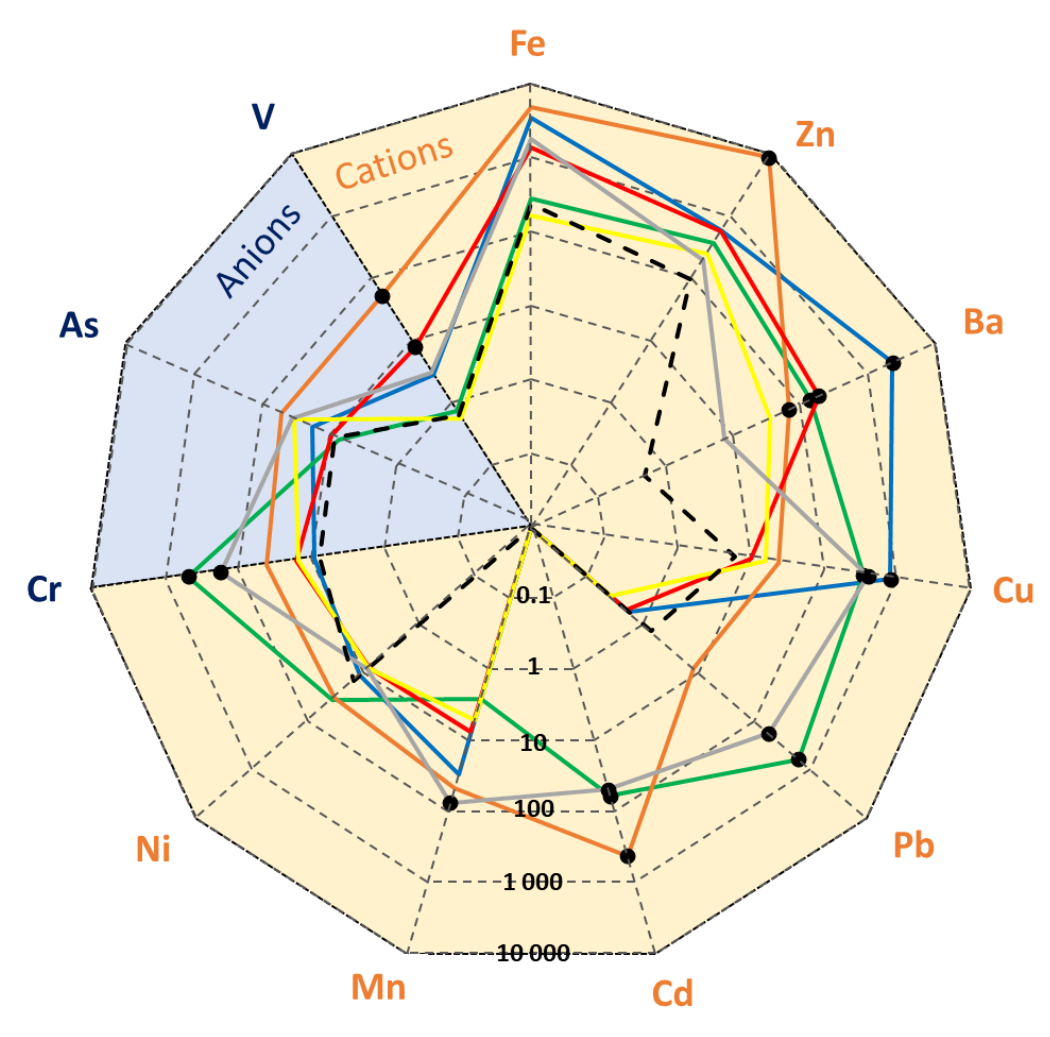

398

399 Figure 4: $\mathrm{S}$ values obtained from acidic leaching and digestion for Fe, Zn, Ba, Cu, Pb, Cd, Mn, Ni, Cr, As and V. 400 For Al, see FIGURE 1 in SI. Metal(loid)s, with low S values (close to the centre) are mainly sorbed onto 401 microplastics. Metal(loid)s, with high $S$ values are additives in the microplastics. 


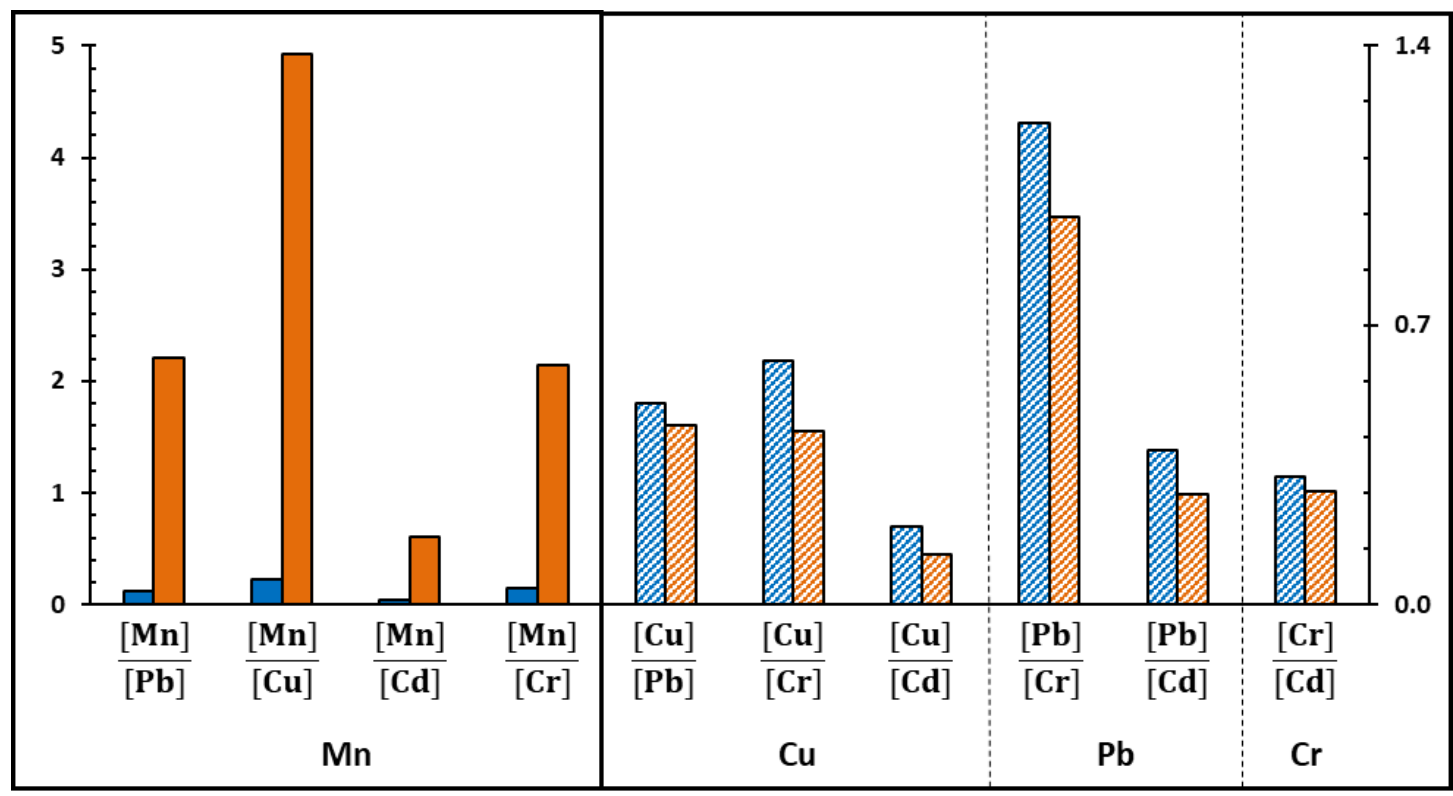

a)

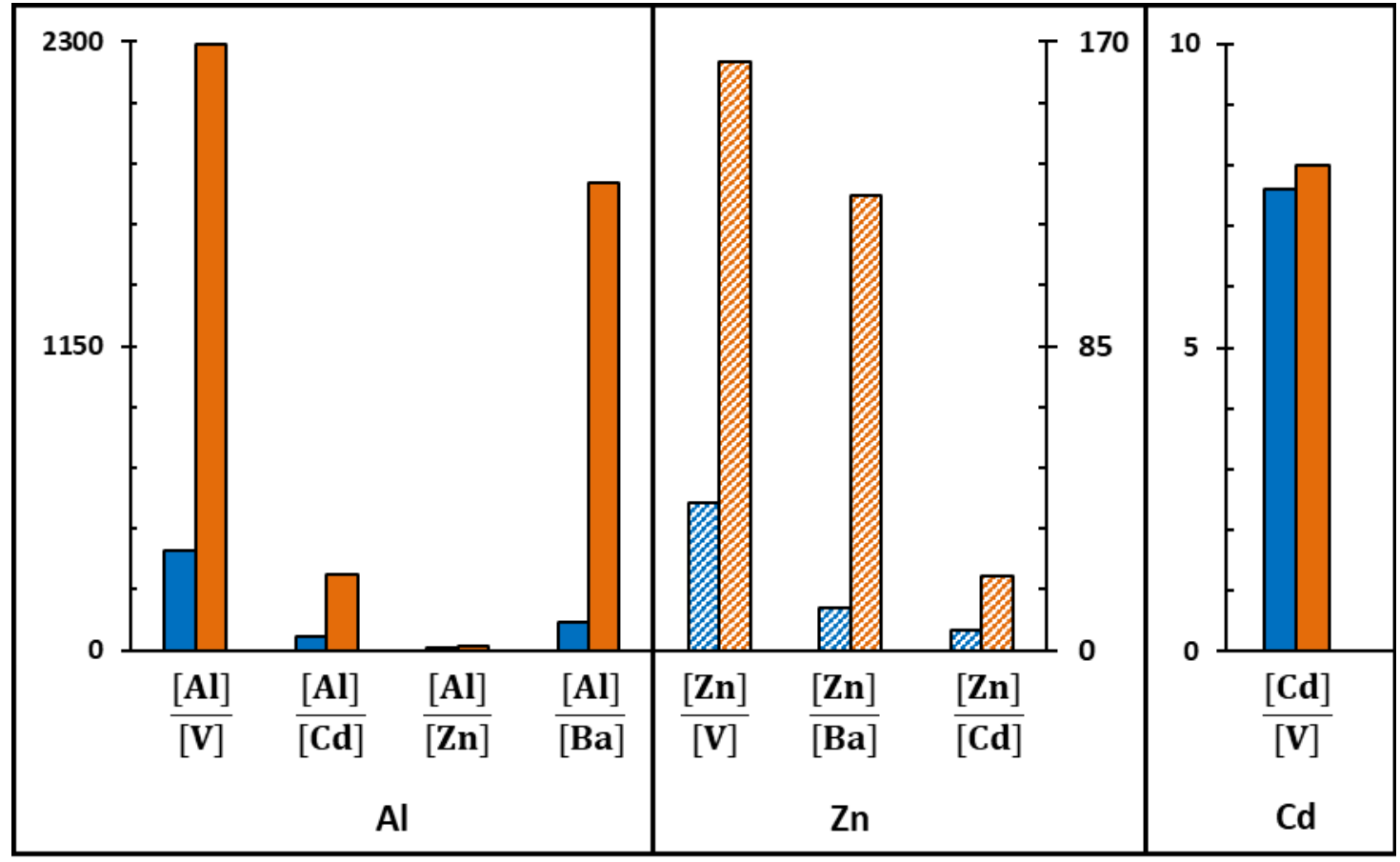

b)

$\square$ Acidic leaching $\square$ Acidic digestion 
403 Figure 5: Metal/Metal ratio of concentration in the acidic leaching and acidic digestion in the a) grey and black 404 sample and b) orange sample. $\mathrm{Cu}, \mathrm{Pb}, \mathrm{Cr}$ and $\mathrm{Cd}$ have similar concentration ratios. $\mathrm{Cu}, \mathrm{Pb}, \mathrm{Cr}$ and $\mathrm{Cd}$ adsorption 405 may originate from the alteration of plastics. Note that if one metal is present at higher concentrations in the acidic 406 digestion than in the acidic leaching, this metal imposes a different metal/metal ratio. Thus, Cu/Mn, $\mathrm{Pb} / \mathrm{Mn}, \mathrm{Pb} / \mathrm{Cu}$, $407 \mathrm{Cr} / \mathrm{Mn}, \mathrm{Cr} / \mathrm{Cu}$ and $\mathrm{Cr} / \mathrm{PB}$ ratios were not represented for part a). Similarly, Zn/Al, Cd/Al and Cd/Zn were not 408 represented for part b). 